\title{
Role of Financial Innovation in Enhancing MSMES Access to Credit: An Empirical Investigation on Tanzania
}

\author{
Wilfred E. Mbowe ${ }^{1}$, Fredrick R. Shirima ${ }^{1} \&$ Deogratius Kimolo ${ }^{1}$ \\ ${ }^{1}$ Bank of Tanzania, United Republic of Tanzania \\ Correspondence: Dr. Wilfred E. Mbowe, Bank of Tanzania, United Republic of Tanzania. E-mail: wembowe@bot.go.tz, \\ wembowe14@gmail.com.
}

Disclaimer: The views expressed in this article are solely those of the authors and do not necessarily represent the opinion of Bank of Tanzania or any other institution.

Received: March 20, 2020

doi:10.11114/aef.v7i3.4777
Accepted: April 30, $2020 \quad$ Available online: May 19, 2020

URL: https://doi.org/10.11114/aef.v7i3.4777

\begin{abstract}
This study assesses the extent to which financial innovations contribute to improving micro small and medium enterprises (MSMEs) access to credit in Tanzania. Information was collected through interviews using a structured questionnaire administered on a sample of 318 respondents. Probit estimates were used for robustness check of the factors that influence MSMEs borrowing behavior.

The findings indicate that factors, which influence MSMEs to borrow money through innovative channels, comprise the need for meeting business start-up, operational and expansion costs. Other factors are in respect of ease of access; convenience; short loan process; and a relatively high degree of control of the loan process by the borrower. In contrast to progress made in improving access to financial services by MSMEs, loan access by individuals or businesses through innovative platforms is still low. Only 28.8 percent acknowledged having received loans through innovative platforms, and coefficient on innovation variable was found to be statistically insignificant. Explaining this anomaly include unfavorable terms of loans; high lending rates, inadequate knowledge; small-size loans; and short repayment period. Meanwhile, loan process time, loan size, loan access (distance) have a higher probability of increasing loan access by MSMEs.

Therefore, there is a need to intensify measures towards enhancing MSMEs access to credit, taking advantage of available innovative platform channels. Increasing efforts towards reducing credit risk will help to lower the lending rates, while moral suasion measures by financial regulators together with borrowers' traceable business-record can as well entice loan providers to offer loans of larger size and longer maturity. Meanwhile, capacity building is imperative in enabling MSMEs to acquire requisite business management skills and inculcate record-keeping culture. Equally crucial is enhancing measures towards maintaining the country's macro-economic stability with a view to boosting demand for credit and improving MSMEs' loan repayment capabilities.
\end{abstract}

Keywords: Tanzania, financial development, financial innovation, credit access, SMEs, empirical analysis

\section{Introduction}

It is now widely acknowledged that the access to reliable and affordable financial services to the majority of the Tanzanians matters in fostering economic development through realization of the industrialization agenda and Vision 2025. This is through a noble role that financial institutions play in transferring funds from surplus spending units (savers) to deficit spending unit (investors), thus promoting efficiency and economic growth, see for example Shaw (1973) and McKinnon (1973). Financial institutions also facilitate a friendlier business environment for both domestic and international transactions.

In recognizing this significant role of financial services, the Government undertook a number of initiatives aiming at putting in place a vibrant financial sector. These initiatives started with the first-generation financial sector reforms that begun in 1991 aiming at allowing the market forces to allocate funds in a more efficient way, enhancing the effectiveness of monetary policy instruments, and to promote competition among financial institutions in order to improve their efficiency. Following the recommendations of the Financial Sector Assessment Program (FSAP), the country embarked 
on the second-generation financial sector reforms that were geared towards increasing efficiency and depth of the financial sector to spur economic growth through facilitating provision of long-term development finance and strengthening micro and rural finance under an enabling policy, legal and regulatory framework, BoT (2016a). Following the policy changes and reforms, the financial sector recorded significant improvements including increased number of private financial institutions; enhanced efficiency and competition, Mbowe (2010) and BoT (2016b) ${ }^{\mathrm{i}}$.

Despite the achievements, small and medium enterprises (SMEs) continue to face challenges in accessing loans from the formal financial institutions. Olomi and Urassa (2008) noted for example that access to finance is the most serious barrier to expansion of SMEs in Tanzania. Partly portraying the severity of the problem, a study by Abdal (2012) suggests that formal financial institutions fund less than one percent of the total demand of approximately eight million MSMEs countrywide. Furthermore, United Nations Industrial Development Organization [UNIDO] study of 2013 indicates that only 14 percent of SMEs had access to credit from formal financial services.

In the effort to solve this problem, the government took a number of initiatives including introduction of SMEs Development Policy in 2003 to create an enabling business environment; and putting in place of a supportive institutional infrastructure that provides for the establishment of micro-finance institutions. It also introduced SME financial schemes including SME credit and export guarantee schemes, SME competitiveness facility, and encouraged establishment of micro-finance banks.

The improvements were also linked with the emergence of 'challenger banks' through financial innovations. These include among others Savings and Cooperative Associations (SACCOS), Village Community Bank (VIKOBA), Accumulating Savings and Credit Associations (ASCA), contract financing as well as mobile financial services. These are explained in the subsequent section.

With these developments, the financial sector recorded significant achievement in providing more avenues to the unbanked and the poor to have access to financial services, Mbowe (2018). The exclusion rate (from formal financial services) declined from 54 percent of the adult population in 2006 to 28 percent 2017, FINSCOPE survey (2017). Unclear though is the understanding on the level to which these innovations in the financial sector have contributed to the improvement in credit access by the Micro, Small and Medium Enterprises (MSME's). Knowing this is essential because finance is an important element for determining the growth and survival of SMEs, ACCA (2009). Finance allows small businesses to undertake productive investments and contribute to the development of the national economy, Beck and Demirguc-Kunt (2006). Specifically, external finance is key for boosting start-up businesses; and it helps in improving the competitiveness of SMEs in the international markets, to expand the businesses and strike linkages of business with the large firms, Osano and Languitone (2016) and United Nations (2005).

Addressing finance challenges faced by MSMEs ${ }^{\mathrm{ii}}$ in Tanzania therefore can help increase MSMEs contribution to the economy; which is currently 27 percent of GDP ${ }^{\mathrm{iii}}$, and employ more than 5.2 million people ${ }^{\mathrm{iv}}$. According to Diao et al. (2016), about 73 percent of the increase in total private non-agriculture employment estimated at 3,331,032 between 2002 and 2012 was created in the informal economy largely by micro and small firms.

The current study seeks to investigate the extent to which financial innovations have contributed in enhancing MSMEs access to credit in Tanzania. Three specific objectives are tackled: a) assessing the level of MSMEs access to credit through innovative platforms in comparison to traditional banking system; b) establishing factors which influence MSMEs to take loans through innovative channels, and the constraints; c) evaluating the statistical importance of innovative platforms and other constraints in enhancing the probability of MSMEs to borrow.

The rest of the paper is organized as follows: after this introduction section, section two provides an overview of financial innovation and financial access by MSMEs in Tanzania. Section three presents a literature review covering both theoretical and empirical literature. Section four describes the research conceptual framework and methodology. Section five discusses the study findings. Section six presents conclusion and policy implications.

\section{Financial Innovation and Financial Access by MSMEs in Tanzania}

As indicated earlier, the second-generation financial sector reforms sought to strengthen micro and rural finance focusing on promoting a viable and sustainable microfinance industry with a wide outreach, operating under an enabling legal and regulatory framework, BoT (2016b). This was important because up to the late 1990s, microfinance sector was uncoordinated with no governing policy, which culminated into the development of the National Microfinance Policy (NMP) in 2000 and the legal and regulatory framework including the development of microfinance regulations in 2005. To further take on board changes in technology and mandate in managing the microfinance sector, the Banking and Financial Institutions (Microfinance Activities) Regulations were put in place in 2014 and amended in 2015. The NMP (2000) was reviewed in 2016 with a view to creating an enabling environment that promotes the development of appropriate and innovative microfinance products and services to meet the real needs of the low-income population in order to enhance economic growth and accelerate poverty reduction, BoT (2017). Other players in this 
area include SACCOS, financial non-governmental organizations, credit only companies and informal microfinance service providers including VICOBA, Accumulating Savings and Credit Associations (ASCA), which are widely spread in the country ${ }^{\mathrm{v}}$. However, information on loans granted through some of these innovative channels are not readily available.

VICOBA is a saving group model that emerged in Tanzania since 2010 focusing on mobilizing financial resources from members engaging in small productive activities through their savings and lending. This product helps to address the adverse selection and moral hazard problems by shifting the responsibility of screening, monitoring and enforcement from lenders to clients. In case of default, group members' savings cater for repayment creating an incentive to make sure right clients are chosen in the group, thus lowering transaction costs; improving service delivery; and increasing accessibility of the service to the SMEs, Asian Development Bank [ADB] study of 2005.

Lease finance was allowed in the country since 2008. Leasing is the medium-term financial instrument aimed at covering the investment needs of the companies for machinery. Leasing is an important source of financing for SMEs as it can be used to finance investment without making a large initial cash outlay, enabling the entrepreneur to match expected income and expenditure. Data available at the Bank of Tanzania indicate that, by the end of December 2017, loans amounting to TZS 35 billion had been provided in the form of leasing.

Mobile phones have also been instrumental in improving access to financial services, mainly contributed by the fast increase in the utilization of mobile telephone technology ${ }^{\mathrm{vi}}$. According to the 2017 Finscope survey, about 79.9 percent of MSMEs had access to banking and non-banking financial services, up from 73 percent in 2013, because of mobile money payment systems. Financial access for smallholder farmers also increased from 14 per cent in 2009 to 59.8 percent in 2017 (FSDT, 2017). Credit only institutions through the mobile phone provided micro loans to the tune of TZS 30.12 billion in 2017.

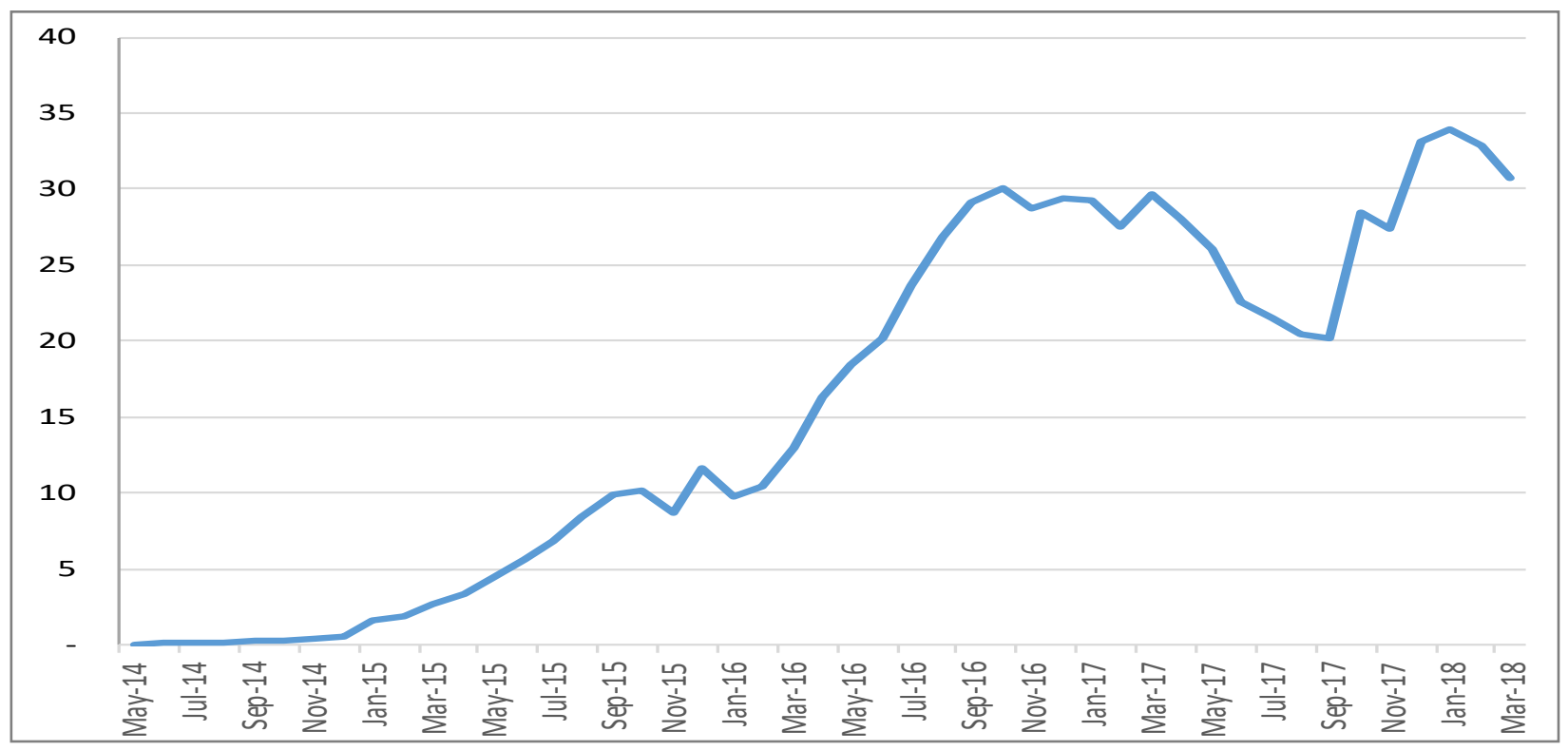

Figure 1. Mobile phone micro loans in billions of Tanzanian Shillings

Source: Bank of Tanzania

\section{Literature Review}

\subsection{Theoretical Literature}

Khraisha and Arthur (2018) note that financial innovation enables "creation, promotion and adoption of new products, platforms, and processes or an enabler of technologies that introduce new ways or changes to the way a financial activity is carried out" (p.4). ${ }^{\text {vii }}$ Financial innovations serve multiple goals and thus, may cover such aspects as enhancing credit generation and availability; transaction costs reduction; transferring and sharing of risks; risk pricing; liquidity management and enhancement; equity generation; and funding of financial institutions.

Financial innovation allows the development of lending platforms, which mediate the flow of information from the conventional banking system to unbanked borrowers and helps in credit risk analysis as well as risks sharing (Financial Stability Board [FSB], 2017). Financial innovation performs intermediation function thus lowering cost of capital, 
Merton (1995), and by helping manage and transfer the extra burden emanating from new and wider risks, Stieglitz (2010).

The study by ACCA (2014) indicates that financial innovation reveals in many shapes and forms including crowd funding, peer-to-peer (p2p) lending, mobile phone system, credit societies, leasing, and hire purchase. Nature of credit provided through innovative financial services varies depending on the business model of the given credit platform. The main intention though is to provide a lending platform that allows lenders/savers to trade directly with the borrowers. Most operate in such a way that, they by-pass the traditional banking system, though some use banking system infrastructure to facilitate transactions.

\subsection{Empirical Literature}

Despite the progress made in innovating ways of supplying credit, SMEs' growth in developing countries still faces challenges, largely associated with difficulties in accessing financial services, Beck (2007). World Bank (2012) indicates that SMEs are more credit-constrained than large firms mainly due to the opaque organizational features and business strategies that are rarely publicly disclosed. The informational opacity limits SMEs access to standardized public markets for equity and debt thus affecting their growth potential, see for example Beck and Demirguc-Kunt (2006) and Beck et al. (2008).

Studies by BBA (2002) and Watanabe (2005) suggest that SMEs access to finance is a supply side issue owing to differences among commercial banks and entrepreneurs. Several other studies have identified lack of competition in the financial sector (distortions) as another crucial setback in the access of financial services, see World Bank (2003). The World Bank (2003) points to other constraints such as lack of know-how on the banking part, information asymmetry (access to business information), and the high risk in lending to small businesses, whereas others suggest size of business and age of the borrower, lack of collateral requirements, high risks, information asymmetries, small credit transactions particularly of rural households, the distance between lenders and borrowers, policy, and type of financial institution, Bigsten (2003) and Yitayal (2004); and firm-level managerial capability, collateral, networking and business information, macro-economy, the legal environment, ethical perception, crime and corruption, see Fatoki and Smit (2011).

In Tanzania, a desk review by Marwa (2014) points to MSMEs' characteristics that impair access to finance. These include small size of operation, weak managerial and business skills, informality of the activities, poor record keeping, information opacity, weak regulation, and lack of property rights. A study by Olomi et al. (2008) acknowledges three major groups of constraints on SMEs access to finance. The first group of factors includes the capacity of the SMEs themselves in terms of the low level of knowledge and skills, the under-developed culture of the business, lack of separation of the business between personal issues and family, the limited credit history of SMEs, and lack of knowledge of available financial services. The second group comprises the number of competent personnel and lack of experience of SMEs, while the third group relates to deficits in the enabling environment in terms of laws that over protect borrowers at the expense of lenders, absence of national identification system and credit reference bureaus. As for the options for SME financing in Tanzania, Mori et al. (2009) and Olomi et al. (2008) indicate loans from commercial banks; funds from semi financial institutions such as SACCOs; and informal financial institutions such as money lenders. The two studies suggest that most SMEs opt for semi and informal financing because of easy accessibility.

Two things emerge from the literature review: first, the factors, which constrain SMEs access to finance, differ across countries including supply-side factors such as type of financial institution and SME internal characteristics, which affect the demand for credit. Financial innovation can perform an intermediation function and lower cost of capital by helping manage and transfer credit risk. Second, both descriptive and quantitative analysis have separately been employed to investigate factors influencing SMEs access to credit. No formal study seems to have empirically assessed the role of innovation in enhancing credit access by MSMEs in Tanzania. This study seeks to contribute to literature on financial innovation and MSME using information from a small but developing economy, Tanzania.

\section{Conceptual Framework and Methodology}

The conceptual framework guiding the investigation is depicted in Figure 2. MSMEs in Tanzania are conceived to finance its activities through various sources. Traditionally regulated financial institutions specifically banks were to be the main source of finance given their size, but as mentioned before that may not always be feasible due to high risks associated with financing MSMEs. In bridging the gap, there are other sources, which are utilized by MSMEs: own or family resources and innovative platforms. The main innovative sources in consideration are MFIs, SACCOS, VIKOBA, MNOs, and leasing and sub-contracting companies. Innovative platforms can enhance MSMEs' access to credit through three ways. First, it is by providing a platform to pull together group contributions and channel them to needy members as it is for VIKOBA and SACCOS; second, by serving as a channel through which individual members 
can access loans from formal financial institutions or non-financial corporations (e.g. SACCOS, lease and contract finance companies; and third, by acting as a delivery channel of loans from formal financial and non-financial institutions (e.g. mobile phone system).

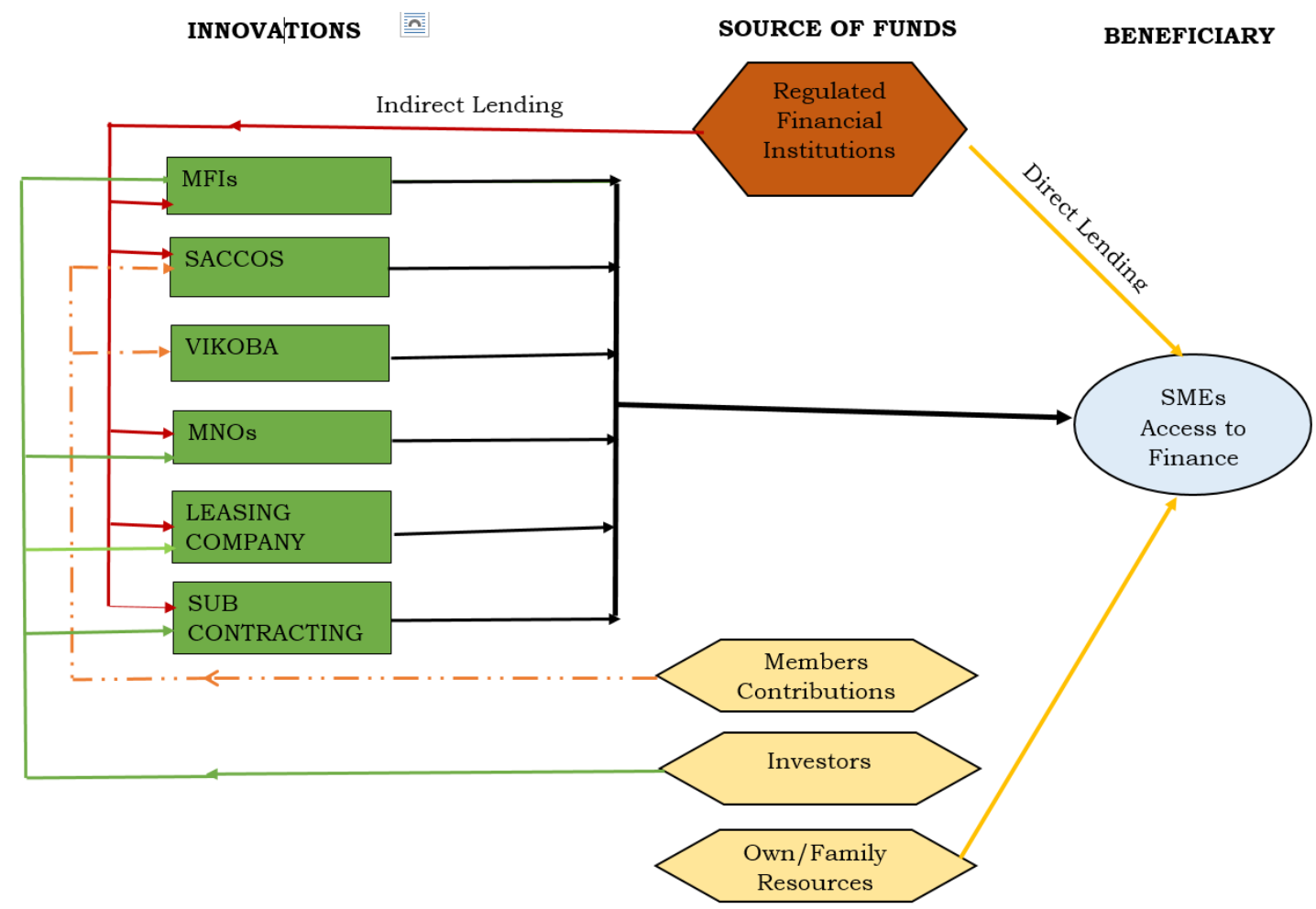

Figure 2. SMEs financing options in Tanzania (authors'construction)

Note: MFIs is Microfinance institutions; SACCOS, Savings and credit cooperative society; VIKOBA, Village community banks; FIs, Financial institutions; MNOs, Mobile network operators; and SMEs denotes micro, small and medium enterprises.

Source: Authors' construction

Interviews using a structured questionnaire were conducted to collect information to provide answers to the research objectives. In order to achieve the desired level of information quality and representativeness, a two-step sampling process was employed. First, regions were ranked along with the number of registered SMEs as provided in the National Bureau of Statistics Industrial Census survey of 2013. The top three regions; two median regions; and one bottom region were selected ${ }^{\text {viii }}$. In the second stage, basing on weight of SMEs concentration across regions, and taking note of the need to balance between urban and rural settings a sample of 318 businesses were randomly selected and interviewed across the six regions in February 2017. The outturn, as well as respondents and firms' characteristics, are as summarized in Appendix II.

The level of MSMEs' access to credit through innovative platforms, reasons for access and constraints are approached through descriptive analysis of the field data. Probit estimation is employed as a robustness check of the key factors that influence MSMEs borrowing behavior, and for testing statistical importance of innovative platforms in boosting MSMEs' credit access probability, mainly benefiting from the cross section field data. MSME access to credit is defined as an individual/business' ability to borrow over the period. The dependent variable takes the value of 1 (if a respondent accessed credit or is expecting to access credit in the future) and 0 (if otherwise). A set of explanatory factors deemed to influence MSMEs behavior in accessing credit and expected signs are explained in Appendix I.

In order to capture the role of financial innovation in improving credit access, a dummy variable is introduced in the model; bearing value of 1 if an innovative platform (SACCOS, VIKOBA, mobile loan facility, MFIs, lease, or contract financing) is accessed, and 0 if otherwise. 
Let, $A_{j}^{*}$, be the benefits accruing to a given firm $j$, in a given location $i$, from accessing finance. The benchmark equation can be specified as:

$$
\mathrm{A}_{j} *=\beta_{\mathrm{O}}+\beta_{1} \chi_{j}+\beta_{2} \gamma_{i}+\sum_{i}
$$

where $A_{j}^{*}$ is the variable that index the measure of MSMEs access to credit; $\quad \chi_{j}$ is a vector representing firm level factors or internal attributes influencing access to credit; $\gamma_{i}$ is the list of factors outside the firm, including industry level characteristics. The dependent variable $A_{j}^{*}$ is not observed since it is a latent variable explaining firm access to loan. Hence the following Probit model is defined:

$$
\mathrm{A}_{j}^{*}=\left\{\begin{array}{l}
1 \text { for } A j>0 \\
0 \operatorname{for}_{j}<0
\end{array}\right\}
$$

where, $A^{*}$ is a binary variable, taking the values of 1 if a firm accessed a loan, and 0 if otherwise. Letting depict the cumulative normal distribution function, the Probit general regression equation can be written as:

$$
\sum\left(\frac{A_{j}}{X_{j}}\right)=\phi\left(a_{0}+a_{j} X_{j}+a_{i} Y_{i}\right)
$$

It is assumed that firms' access to finance may be influenced by internal factors comprising firm ownership; owner's gender, age, level of education, perception about loan default risk; while external factors include availability of financial innovation platforms, distance between the lender and borrower, loan size, and loan repayment period. Therefore, the model takes the form indicated in equation (4), where $\alpha$ is the intercept; $\varepsilon_{t}$, the error term; and $j=1 \ldots 10$.

$$
\mathrm{A}_{i}^{*}=\alpha+\beta_{j} \chi_{j}+\varepsilon_{i}
$$

\section{Discussion of Study Findings}

\subsection{Level of Credit Access through Innovative Platforms}

In assessing the level of credit access through innovative platforms, respondents were asked to: first, indicate the main source of finance for their businesses. Three channels of finance are revealed by respondents: banks; financial innovation platforms such as MFIs, SACCOS, saving groups, leasing, subcontracting, mobile network operators; and non-financial institution sources, mainly family or friends, individual lenders and government. Compared to banks, the findings point to a relatively weak role of innovative platforms in terms of credit access by MSMEs. However, innovative platforms are far important relative to non-financial institution sources. In particular, only 28.8 percent of the respondents interviewed in February 2017 indicated to have received loans through innovative platforms (Figure 3).

Second, respondents were required to rank different sources of finance based on their perceived relevance, in a scale of 1 (most important), 2 (important), and 3 (least important). Innovative platforms were ranked "important" or "most important" by only 29 percent of the respondents, largely driven by saving groups, MFIs, and SACCOs (Figure 4). The findings compare unfavorably with the country's achievements in MSMEs access to overall banking and non-banking financial services, which in 2017 was 79.9 percent. The weak role of innovative platforms in credit access bonds well with the low share of credit to MSMEs, which according to IPC (2018) is around 14.8 percent. 


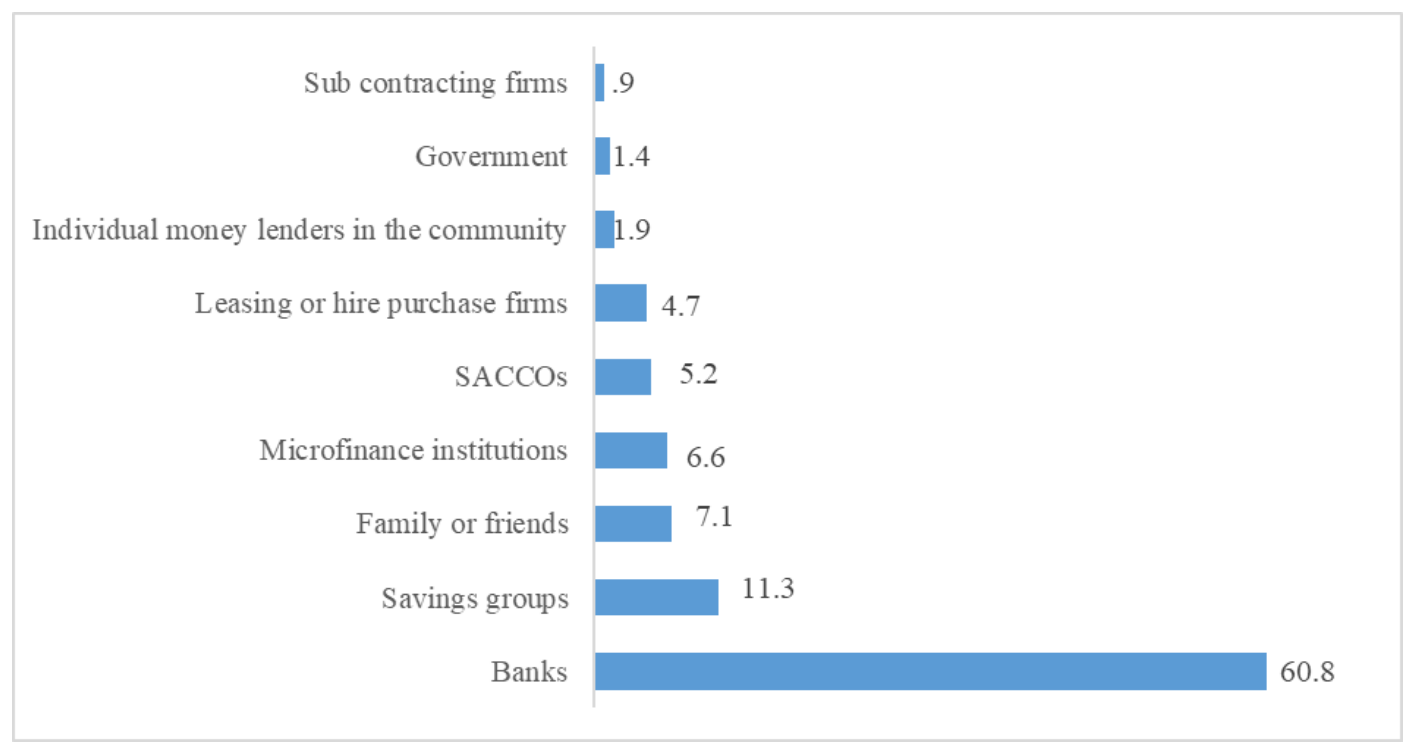

Figure 3. Main channels of loans for MSMEs (percent)

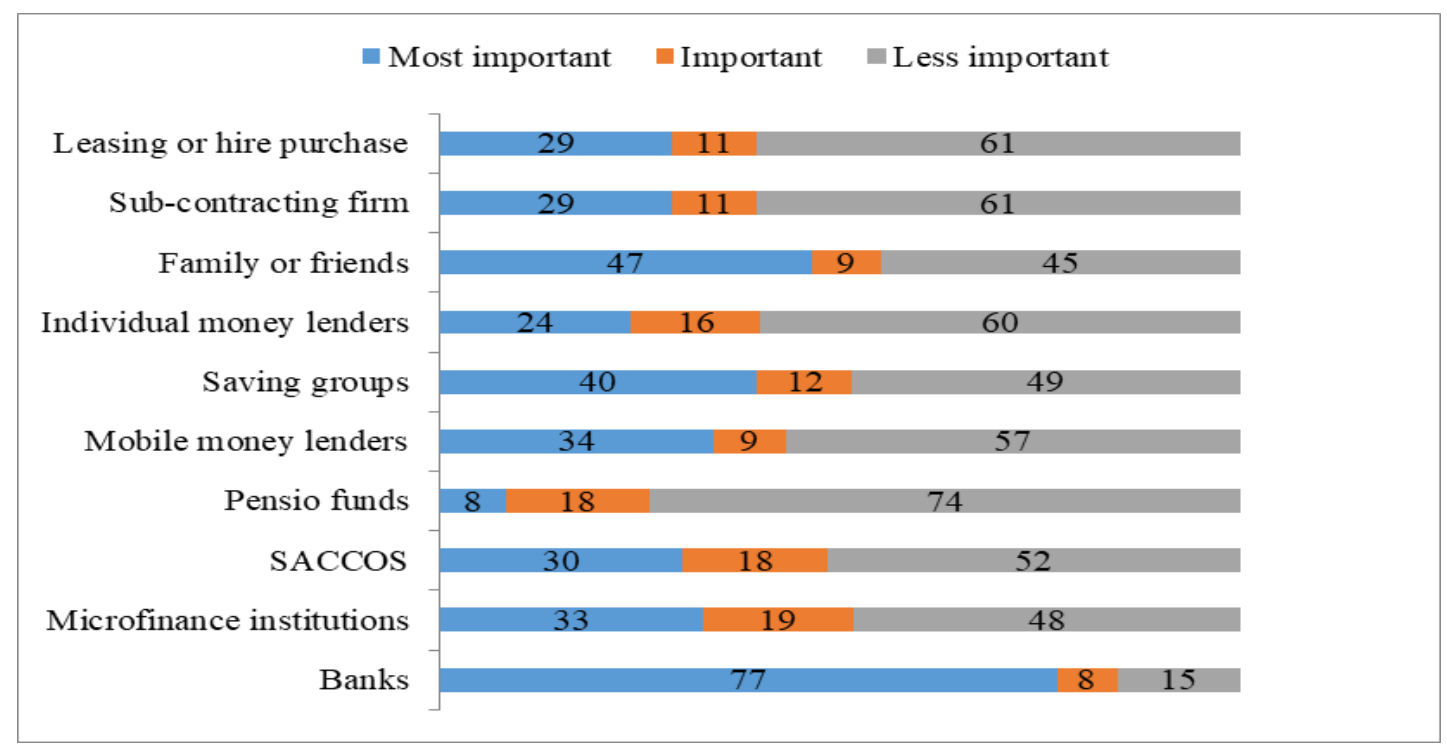

Figure 4. Ranking of different sources of credit

\subsection{Factors Influencing Loan Access through Innovative Channels}

Different factors explain why MSMEs borrow money through innovative channels. Basing on respondents' perception one set of the factors is in respect of the necessity of finance in supporting business, while the other set is related to borrower's characteristics; and supply aspects such as ease of access; convenience; and time taken to acquire a loan. Most of the interviewed MSMEs need loans to support business expansion and operational costs (Figure 5). Accounting for loans from banks and non-financial institutions, start-up capital also features as another vital reason (Appendix IIIA). As indicated in Figure 6, most of the borrowers are in micro to small businesses, probably supporting the thrust for expansion. According to CGAP (2013), micro and small entrepreneurs have a very small capital base; starting capital is usually sourced from their meager savings, loans from friends and relatives. As the businesses grow, their needs extend beyond own and family lending and savings into other financial products, such as loans which are offered by banks and non-bank institutions. 


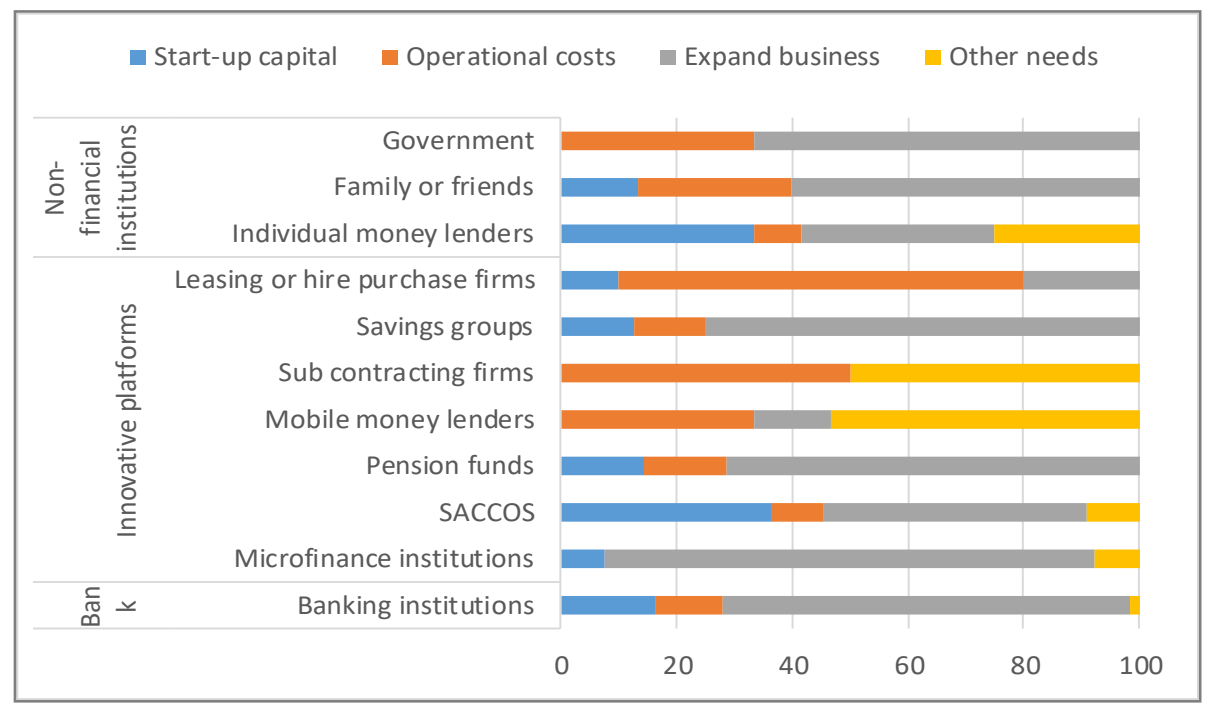

Figure 5. Main purpose for borrowing loans through innovative platforms (percent)

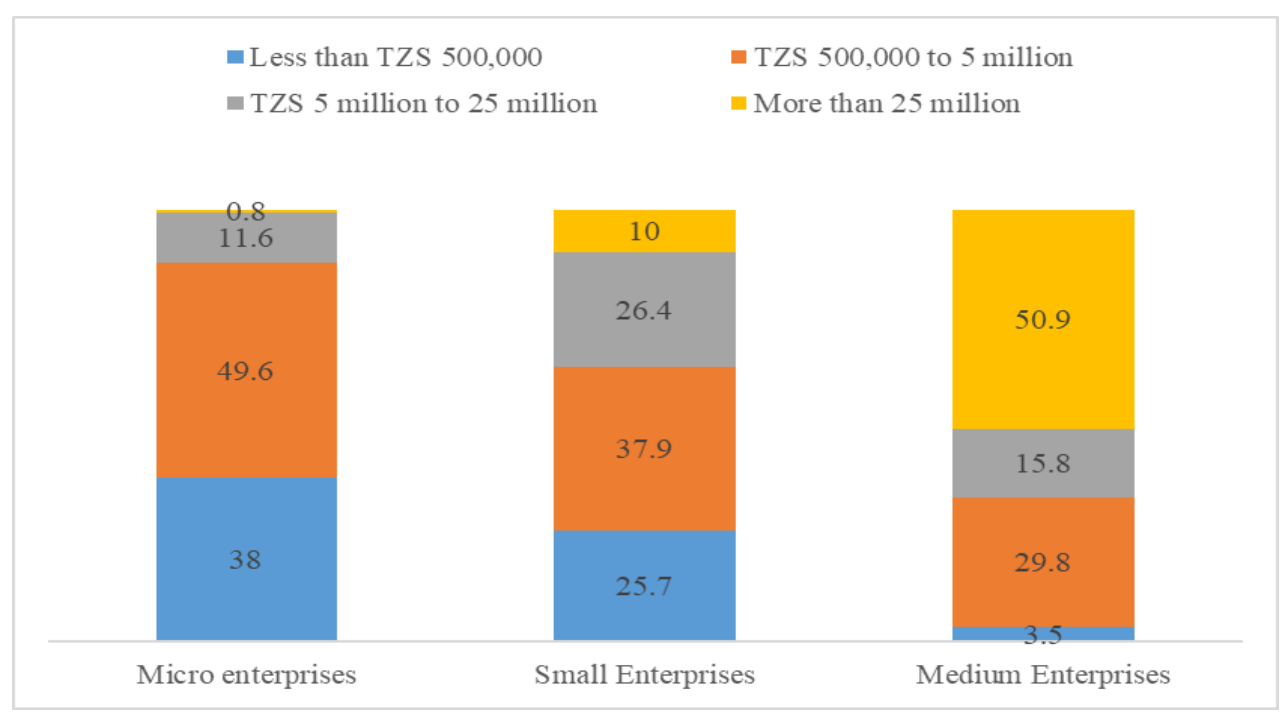

Figure 6. Loan amount in relation to business size (percent)

Innovative platforms tend to be favored by female, working age and less educated cadre. This is largely in respect of saving groups, SACCOS and micro-finance, which normally provide small loans mainly in support of micro- and smallbusinesses particularly in agriculture, trade and manufacturing (Figure 7 and 8). This implies that policies directed at promoting lending through innovative channels could help improve the welfare of the marginalized people in the society such as women and less educated people, partly by helping them to grow their businesses. 


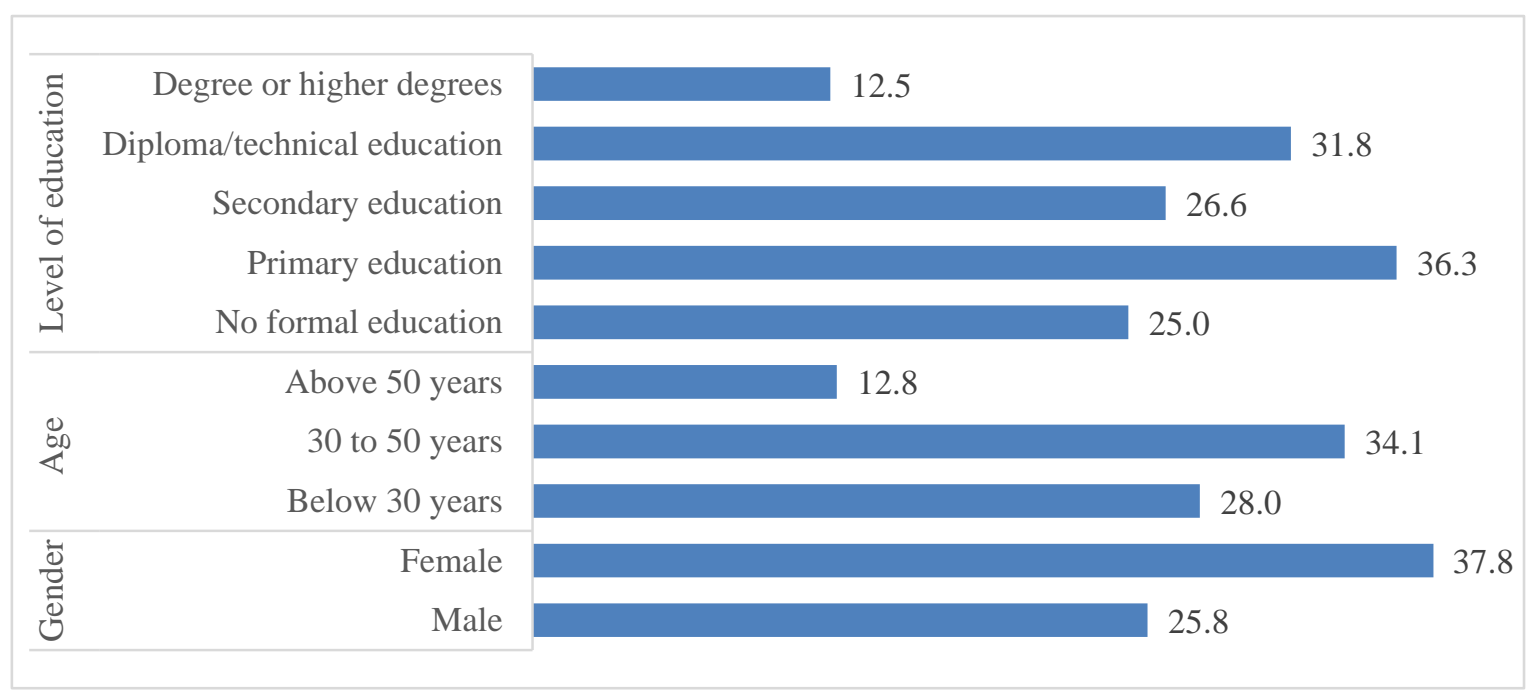

Figure 7. Borrowing through innovative channels by respondents characteristics (percent)

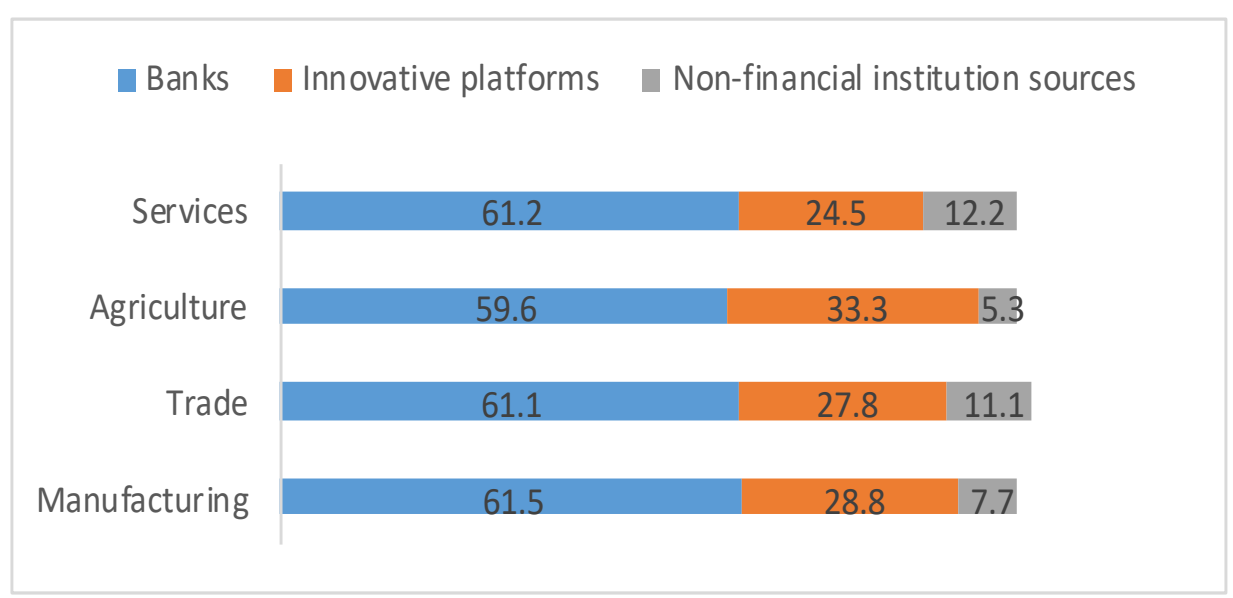

Figure 8. Borrowing through innovative platforms by activity (percent)

Other reasons for choosing innovative channels are in relation to quick access and speedy loan process (Figures 9 and 10). Quick access seems to be higher for sub-contracting, microfinance, SACCOS and saving groups. Some degree of control of a channel is also important. Savings group, for example, is perceived to be most convenient to handle trailed by SACCOS; this is because respondents are part of the groups making it possible to influence decisions (Figure 11). Meanwhile, processing of a loan through innovative platforms such as mobile network is considered to be faster than other modes; it takes less than a week to get a loan. Other innovative platforms fall in the rage of one to four weeks, with microfinance, sub-contracting, SACCOS, leasing and hire purchase taking longer time, partly due to the want to allow for screening to reduce adverse selection and information asymmetry risks. 


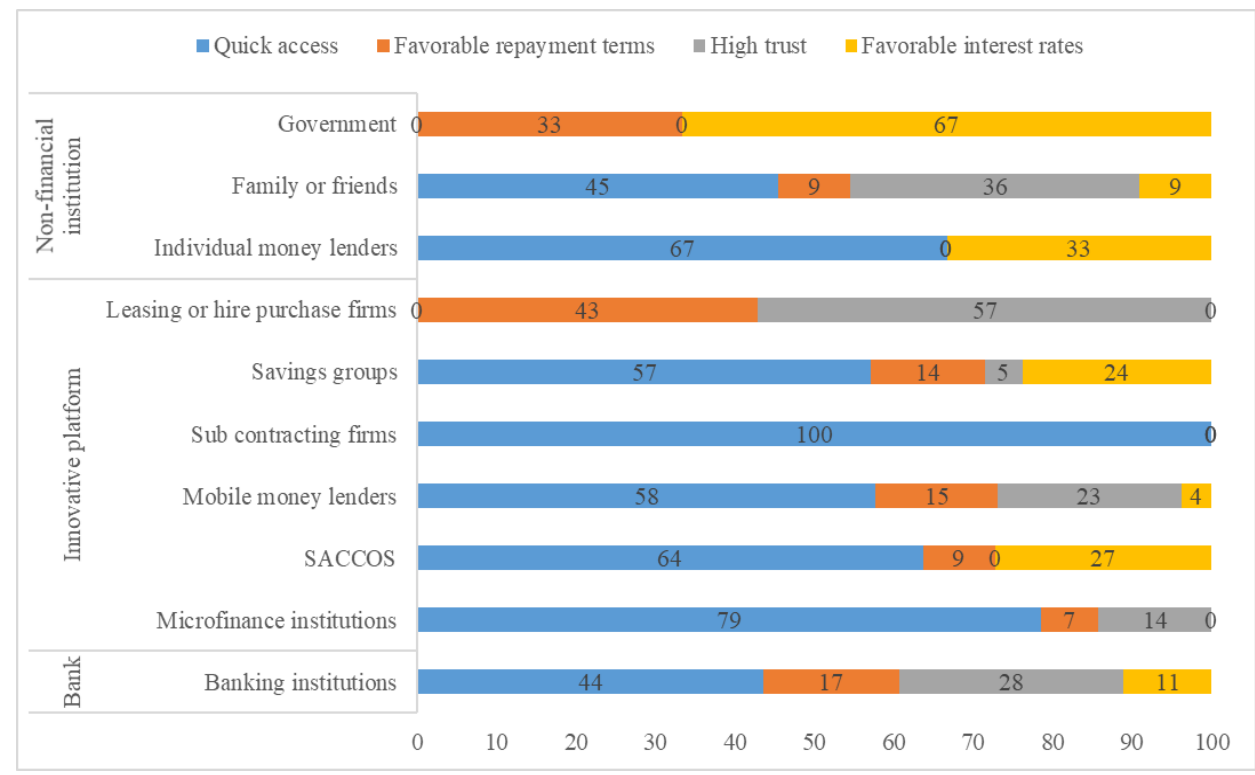

Figure 9. Other reasons for borrowing money through innovative channels (percent)

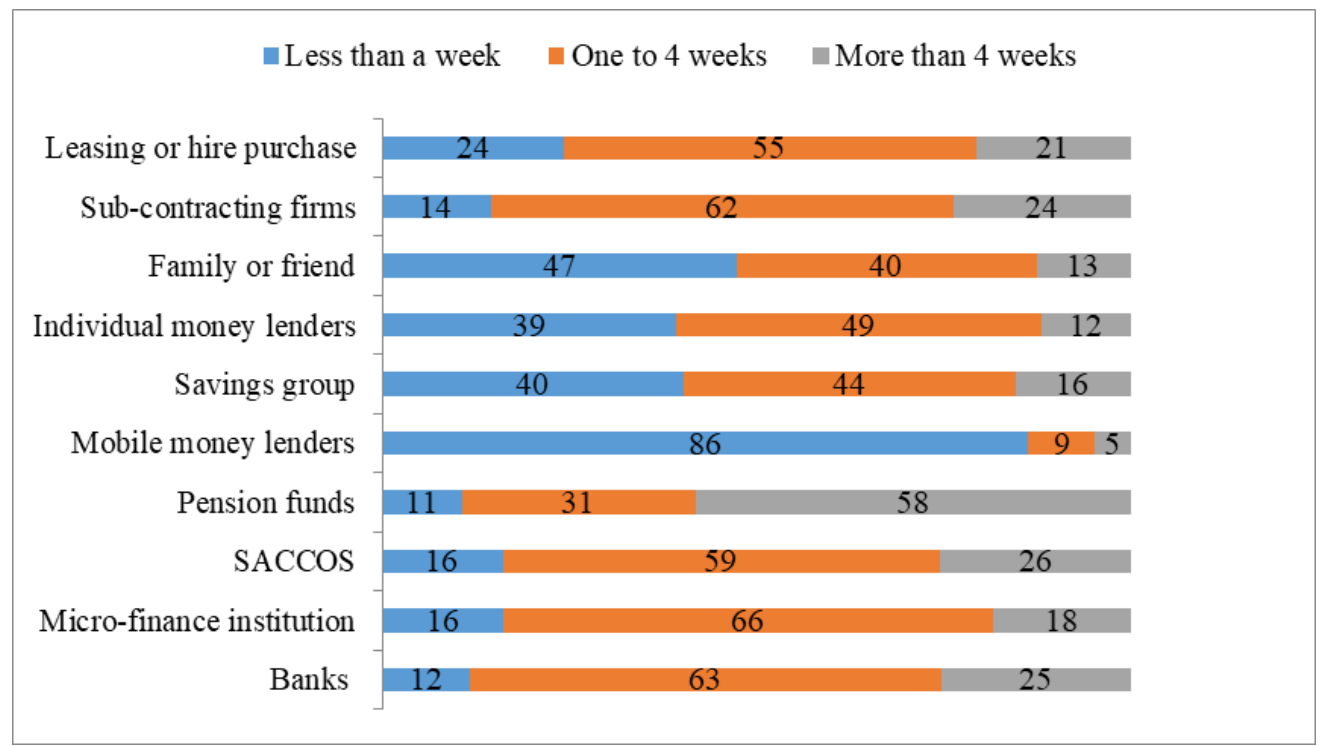

Figure 10. Time taken in loan processing by the source of finance (percent)

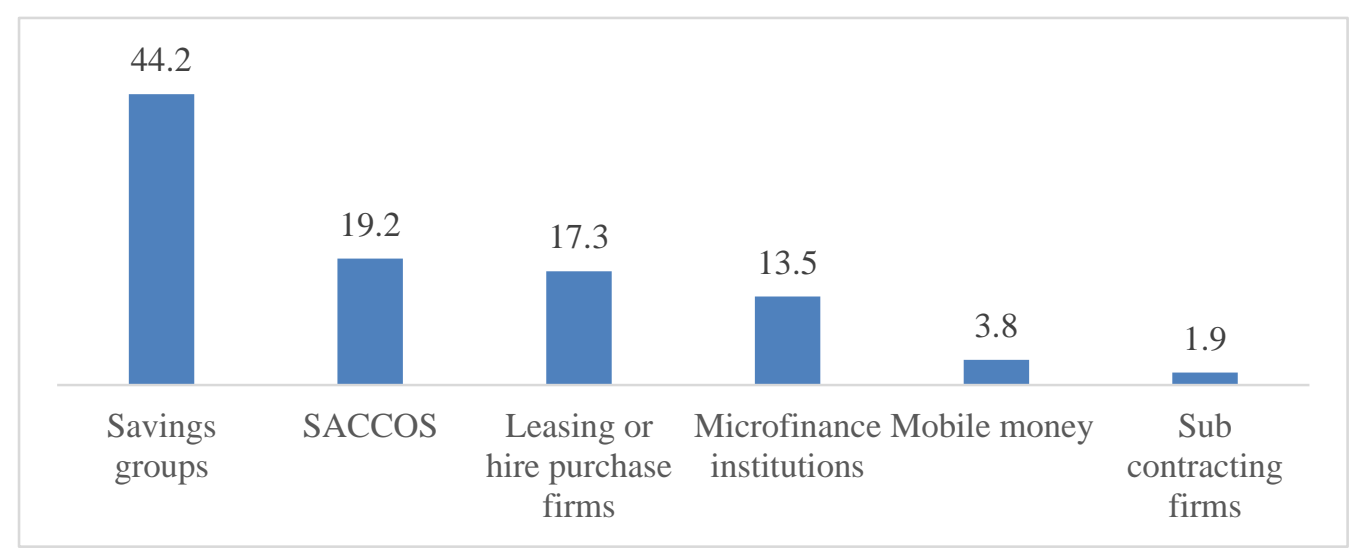

Figure 11. Most convenient innovative source of finance to deal with (percent) 


\subsection{Respondents Perception about Factors Constraining Access to Finance}

Besides low access to credit through innovative channels, the results indicate that only half (50.6 percent) of 318 respondents borrowed money from different sources, while 39.9 percent had a plan to borrow in the future. In explaining this anomaly, respondents point to varying constraints, some of which are specific to innovative channels. Figure 12 summarizes respondents' views about factors, which limit access to credit through innovative channels, while responses on all finance sources are provided in Appendix IIIB. All responses taken together, the factors can generally be grouped into three groups: firm characteristics, supply-side factors, and business environment factors. On demand side, these are in relation to MSMEs low capacity in business management, small operations, lack of knowledge about available finance opportunities, and misuse of borrowed funds. Supply-side factors include high interest rates, unfriendly collateral terms, length loan processing time, short repayment period, and small-size loan. Unpredictable business environment largely due to price and power volatility also impact MSMEs negatively. Specific to innovative channels are: unfavorable terms of loans, high cost of credit, small loan size, low awareness on available innovative platforms, and the short loan repayment period.

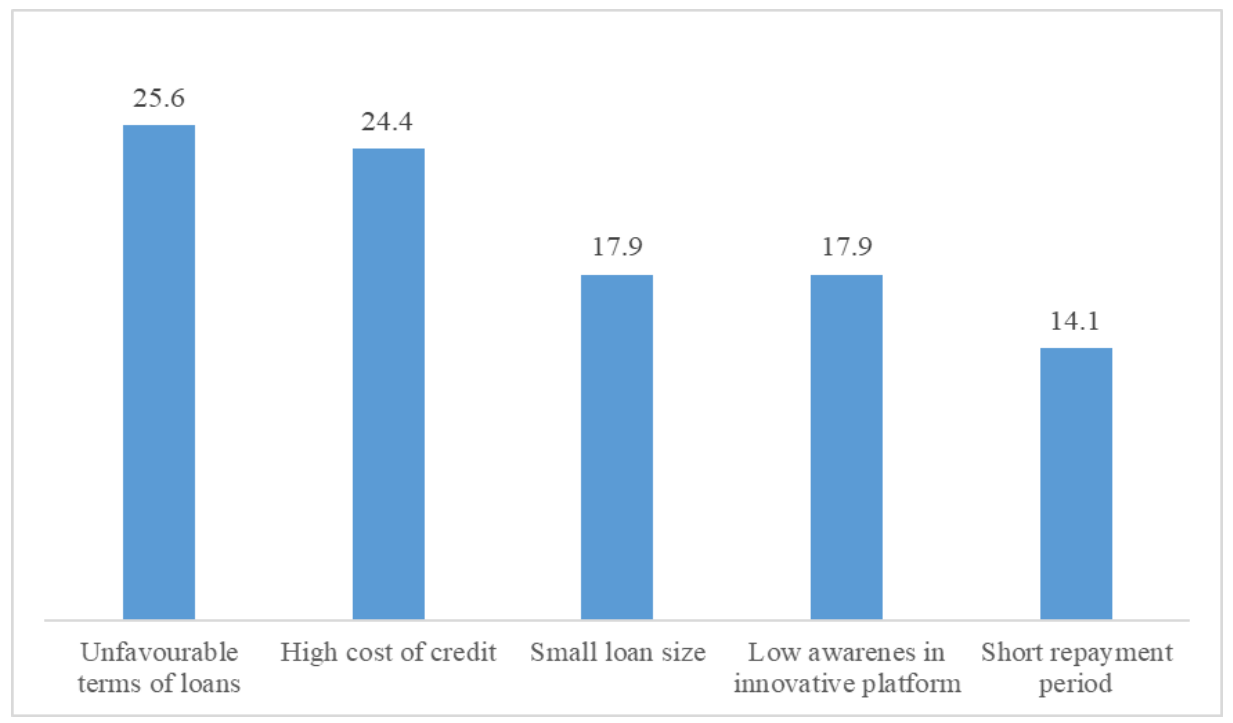

Figure 12. Ranking of credit access constraints related to innovative platforms (percent)

Cost of funds and collateral stand out prominently. The finding augers well with that in FSDT's National Baseline Survey Report for Micro, Small, and Medium Enterprises in Tanzania (2012), where almost one third of MSMEs did not borrow from formal and informal financial sources as they were "scared". Studies such as those of Kimuyu and Omiti (2002), Bernejee and Duflo (2004); and Waari and Mwangi (2015) show that interest rate is a good predictor of the amount of loan accessed by SMEs, as well as the possibility of high lending rates to discriminate against newer and smaller firms. Lack of and fear to lose collateral can also constrain access to finance as some of the collaterals involve assets, which to most respondents are essential for survival; these comprise living or business building, family pierce of land, and household amenities (Figure 13). HongboDuan et al (2009), ACCA (2009) and Mwarari (2013) note for example that, due to lack of collaterals and guarantees, SMEs may find it hard to access loans even from the state-controlled financial institutions, and so it could be amidst significant financial innovation, Beck, 2007). Another constraining factor is the requirement to have cash or own deposits as collateral for loans (Figure 14). Such requirement is daunting given small-size operations of most of MSMEs, which are associated with unpredictable cash flows. The two factors may limit savings from the businesses. About 94.5 percent of respondents serviced their loans through funds generated within the business (Figure 15). 


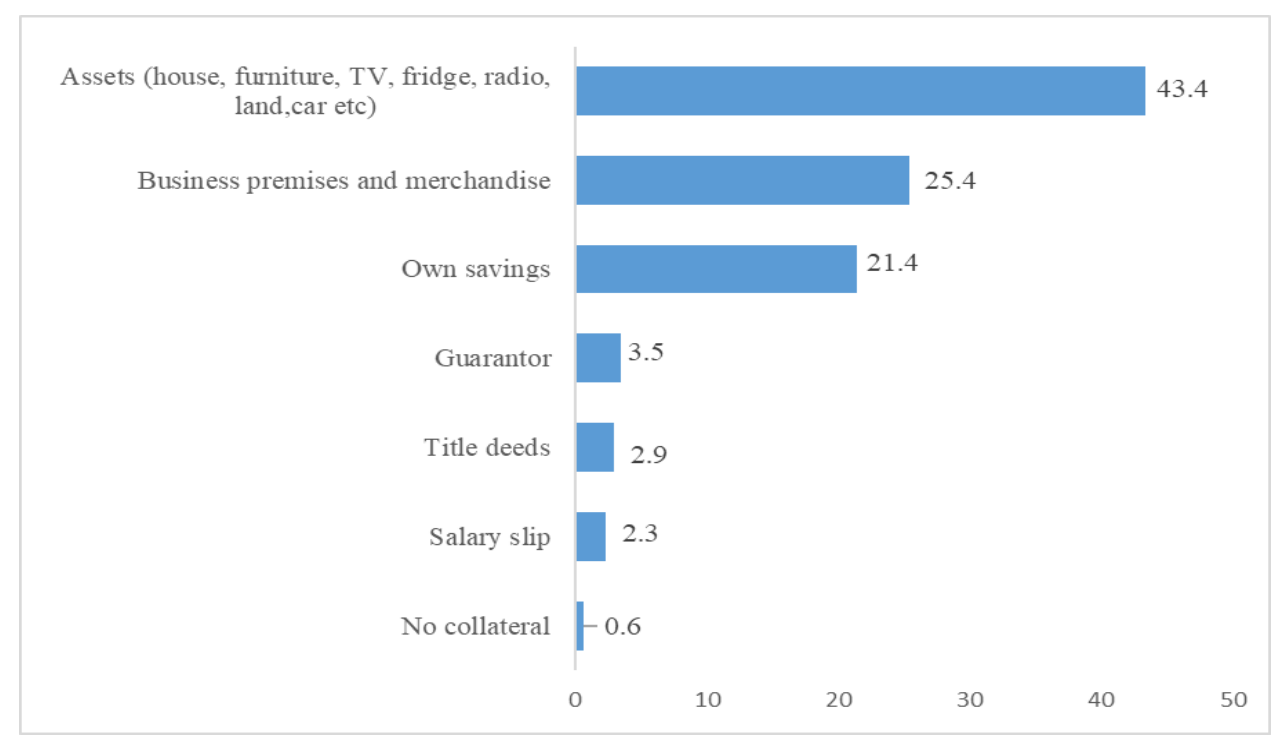

Figure 13. Type of collateral pledged for a loan across all finance channels (percent)

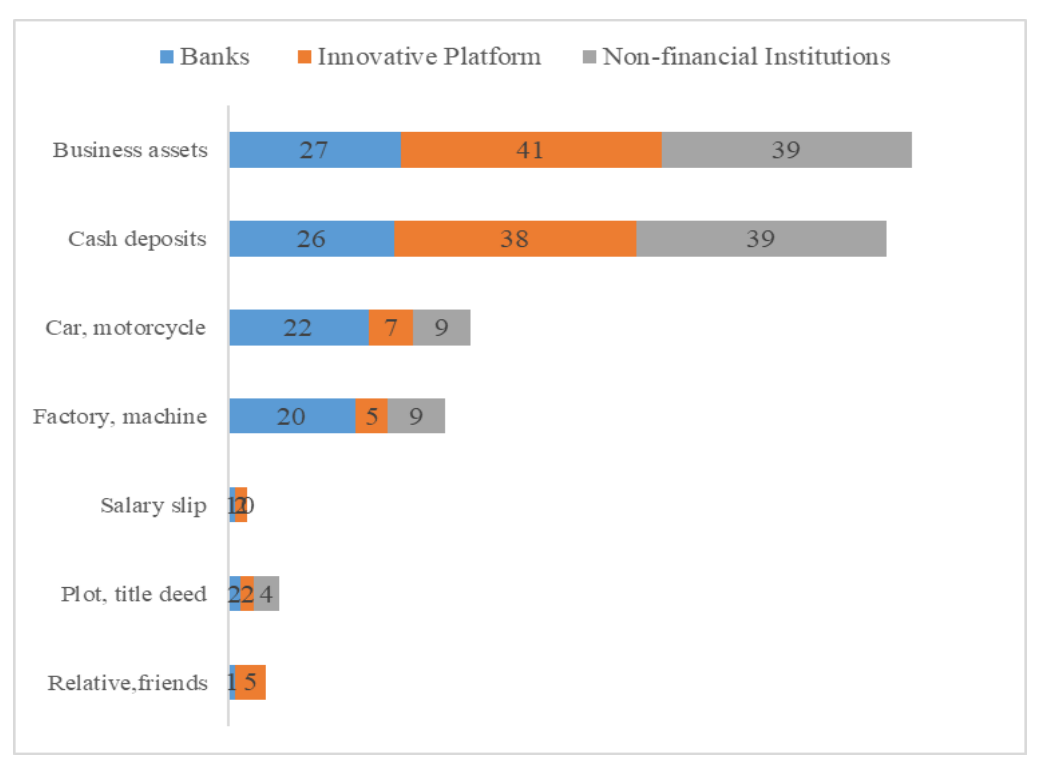

Figure 14. Type of collateral pledged for a loan across credit sources (percent)

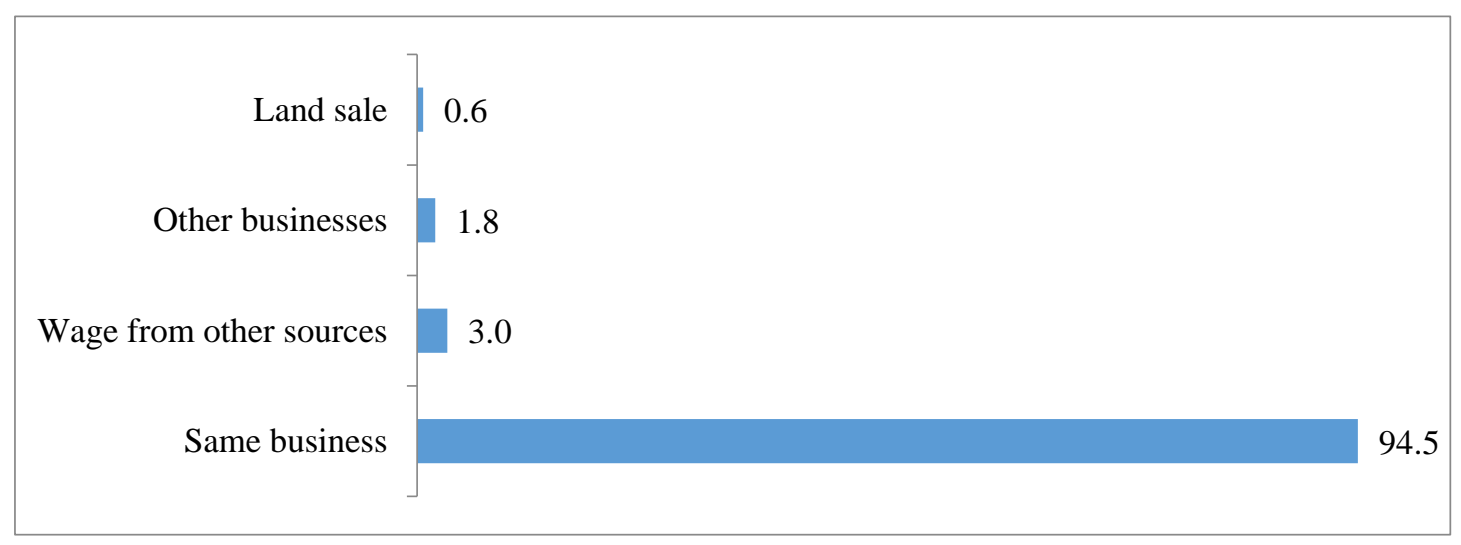

Figure 15. Source of funds to service loans (percent) 


\subsection{Probit Estimation of Factors Influencing MSMEs Credit Access Behaviour}

As a robustness check, constraints barring MSMEs from accessing finance are investigated further through regression analysis with a view to evaluating their statistical significance and relative importance. The estimations also aid in gauging the statistical importance of innovative platforms in increasing the probability of MSMEs to borrow. As indicated earlier, the variables and expected coefficient signs are captured in Appendix I. Probit regression results are summarized in Table 1, while the summary statistics are in Appendix IV.

The Probit results indicate that:

First, coefficient of innovation variable is positive indicating increasing probability of MSMEs borrowing with innovative platform availability, but it is statistically insignificant partly mirroring the low uptake of loans through innovative platforms.

Second, with respect to other factors, distance from the borrower and lender; borrower's perception about lending process; and risks of losing collateral; loan size; and loan repayment period are found to be statistically significant, suggesting that they play a role in influencing MSME's probability to take loans as well. As loan size and repayment period increase, and borrowers perceive the lending process to be easy, the probability of MSMEs taking loans also increases. The probability to borrow tends to be lower if borrowers perceive the borrowing to be risky (i.e., cost of loans is high).

Third, loan process time, loan size, loan access (distance) have a higher probability of improving loan access by MSMEs.

Table 1. Probit regression results

Model: Probit, using observations 1-318 $(\mathrm{n}=315)$

Missing or incomplete observations dropped: 3

Dependent variable: Credit access by MSMEs

QML standard errors

\begin{tabular}{|c|c|c|c|c|c|}
\hline & Coefficient & Std. Error & $\mathbf{Z}$ & p-value & \\
\hline Constant & 0.683496 & 0.680359 & 1.005 & 0.3151 & \\
\hline Age between 30 to 50 & 0.0219642 & 0.248566 & 0.08836 & 0.9296 & \\
\hline Age above 50 & -0.297435 & 0.299172 & -0.9942 & 0.3201 & \\
\hline Gender & -0.446353 & 0.212415 & -2.101 & 0.0356 & $* *$ \\
\hline Primary education & -0.0482004 & 0.375842 & -0.1282 & 0.8980 & \\
\hline Secondary education & -0.279337 & 0.388814 & -0.7184 & 0.4725 & \\
\hline Technical education & -0.189617 & 0.439744 & -0.4312 & 0.6663 & \\
\hline Degree education & -0.493593 & 0.424213 & -1.164 & 0.2446 & \\
\hline Distance less than $5 \mathrm{~km}$ & 0.676698 & 0.216123 & 3.131 & 0.0017 & $* * *$ \\
\hline Loan process easy & 0.941429 & 0.165429 & 5.691 & 0.0001 & $* * *$ \\
\hline Loan risky & -1.02991 & 0.555023 & -1.856 & 0.0635 & $*$ \\
\hline Loan 500,000-5 million & 0.401251 & 0.197447 & 2.032 & 0.0421 & $* *$ \\
\hline Loan 5-25 million & 0.725675 & 0.245529 & 2.956 & 0.0031 & $* * *$ \\
\hline Loan above 25 million & 0.908478 & 0.357008 & 2.545 & 0.0109 & $* *$ \\
\hline Loan repayment period & 0.0250812 & 0.0120110 & 2.088 & 0.0368 & $* *$ \\
\hline Business size & $1.62106 \mathrm{e}-010$ & $1.19395 \mathrm{e}-010$ & 1.358 & 0.1745 & \\
\hline Innovation platform & 0.0229654 & 0.199611 & 0.1151 & 0.9084 & \\
\hline Mean dependent variable & 0.663492 & \multicolumn{2}{|c|}{ S.D. dependent var } & \multicolumn{2}{|c|}{0.473267} \\
\hline McFadden R-squared & 0.236444 & \multicolumn{2}{|c|}{ Adjusted R-squared } & \multicolumn{2}{|c|}{0.151946} \\
\hline Log-likelihood & -153.6182 & \multicolumn{2}{|l|}{ Akaike criterion } & \multicolumn{2}{|c|}{341.2364} \\
\hline Schwarz criterion & 405.0302 & \multicolumn{2}{|l|}{ Hannan-Quinn } & \multicolumn{2}{|c|}{366.7244} \\
\hline
\end{tabular}

Note: Number of cases 'correctly predicted' $=243(77.1 \%)$;

$\mathrm{f}$ (beta'x $)$ at mean of independent vars $=0.473$;

Likelihood ratio test: Chi-square $(16)=95.1395$ [0.0000];

Test for normality of residual - 
Null hypothesis: error is normally distributed;

Test statistic: Chi-square (2) $=2.19755$

with p-value $=0.333279$;

$* * *(* *) *$ statistically significant at $1 \%(5 \%) 10 \%$ level.

Source: Authors estimation using field data.

\section{Conclusion and Policy Implications}

The study attempts to evaluate the extent to which financial innovations contribute to enhancing MSMEs' access to credit in Tanzania using interview and probit estimation approach. The findings suggest that different factors explain why MSMEs borrow money through innovative channels, including the need for meeting business start-up, operational, and expansion costs, ease of access, convenience, short loan process, and degree of control of the loan process by the borrower. Nevertheless, in contrast to progress made in improving access to formal financial services, largely contributed by financial innovation and technological changes, access to credit by MSMEs through innovative channels, is still low. Out of 318 respondents, only 28.8 percent acknowledged to have received loans through innovative platforms, i.e., MFIs, SACCOS, saving groups, leasing, subcontracting, mobile phone system. The Probit estimates indicate a positive sign on the coefficient of innovation variable, but it is statistically insignificant. Respondents point to a combination of factors to explain this anomaly. These include unfavorable terms of the loan (collaterals); high cost of loans inadequate knowledge about loans provided through available innovative platforms; small-size of offered loans; and the short repayment period. Other factors, which influence MSMEs' general access to credit are in relation to customers' awareness on business management; loan processing period; and business environment. Partly due to these difficulties, only half (50.6 percent) of respondents had borrowed money, while 39.9 percent had a plan to borrow in the future.

Probit results suggest that, borrower's perception about lending process and risks of losing collateral, loan size, and loan repayment period are statistically significant, suggesting that they play a key role in influencing MSME's probability to borrow. As loan size and repayment period increase and borrowers perceive the lending process to be easy the probability of MSMEs taking loan also increases, while the probability to borrow tends to be lower if borrowers perceive the borrowing to be risky. Meanwhile, loan process time, loan size, loan access (distance) have a higher probability of increasing loan access by MSMEs.

These findings imply that there is a need to intensify measures towards enhancing MSMEs access to credit, partly taking advantage of available innovative platform channels. These include intensifying efforts in reducing credit risk, which is important for lowering lending rates. Such measures include enforcing 'know your customer' and mandatory use of the credit reference system for tracking borrowers' trustworthiness. Strengthening of the regulatory and supervisory role is similarly fundamental largely to reduce unfair terms of loans; ensure collateral protection; reduce transaction costs; improve service delivery; and ensure the sustainability of financing through innovative sources such as SACCOS, microfinance, leasing, subcontracting, and mobile phone systems. Moral suasion measures by financial regulators together with traceable business-record could as well lure loan providers to offer loans of larger size and maturity. Here, capacity building is important to enabling MSMEs to acquire requisite business management skills and inculcating record-keeping culture. Maintaining the country's high economic growth momentum together with stable inflation are also likely to continue to boost demand for credit and improve MSMEs' loan repayment capabilities.

\section{Acknowledgement}

The authors are grateful to Bank of Tanzania's management for their financial support that made it possible to accomplish this study as planned.

\section{References}

Abdul, A. (2012). Impact of Microfinance Institutions on Growth of Micro and Small Enterprises and Owners in Tanzania. PhD Proposal. University of Dar Es Salaam Business School.

ACCA. (2009). Access to finance for small and medium enterprises. The Evidence and the Conclusion. The Association of Chartered Accountants, October 2009.

ACCA. (2014). Innovations in access to finance for SMEs. The Association of Chartered Accountants, February 2014.

ADB. (2005). ADB-OECD Study on enhancing financial accessibility for SME. Lessons from recent crises. Mandaluyong City, Philippines: Asian Development Bank, 2013.

Ayyagari, M., Demirguc-Kunt, A., \& Maksimovic, V. (2008). How important are financing constraints? The role of 
finance in the business environment. World Bank Economic Review, 22, 483-516. https://doi.org/10.1093/wber/lhn018

Banerjee, A. \& Duflo, E. (2004). Do firms want to borrow more? Testing credit constraints using a directed lending program. Mainline Publishers.

Bank of Tanzania. (2016a). Tanzania Financial Stability Report of September 2017. Bank of Tanzania, Dar es Salaam.

Bank of Tanzania. (2016b). $50^{\text {th }}$ Anniversary of Bank of Tanzania. Evolution of Role and functions. Dar es Salaam.

BBA. (2002). Ethnic minority business in the UK: access to finance and business support. London: British Bankers Association Research Report.

Beck, T., \& Demirguc-Kunt, A. (2006). Small-medium enterprise sector: Access to finance as a growth constraint. Journal of Finance and Banking, 30(11), 2931-2943. https://doi.org/10.1016/j.jbankfin.2006.05.009

Beck, T., Demirguc-Kunt, A., Laeven, L., \& Levine, R. (2008). Finance, firm size, and growth. Journal of Money, Credit and Banking, 40, 1379-405. https://doi.org/10.1111/j.1538-4616.2008.00164.x

Bigsten, A. (2003). Credit constraints in the manufacturing enterprises in Africa. Journal of African Economics, 12(1), 104-125. https://doi.org/10.1093/jae/12.1.104

CGAP (2013). Financing Small Enterprises. What role for MFIs institutions? Washington, D.C, GAP 1818 H Street, NW MSN P3-300 Washington, DC 20433 USA.

Chauke, P., \& Motlhatlhana, M. (2013). Factors influencing access to credit. A case study of smallholder farmers in the Capricorn District of South Africa. University of Venda, Thohoyandou, 0950, South Africa, February 2013.

Cuevas, C., \& Anderson, J. ( 2016). Smallholder households: Understanding demand, driving innovation. 2017, 1825 I Street, NW 7th floor Washington, DC 20006.

Diao, X., Kweka, J., \& McMillan, M. (2016). Economic Transformation in Africa from the bottom up. Evidence from Tanzania. NBER Working Paper No. 22889. https://doi.org/10.3386/w22889

Fatoki, O., \& Smith, A. (2011). Constraints to credit access by new SMEs in South Africa: A supply-side analysis: African Journal of Business Managements; January 2011.

FSB. (2017). Financial Stability Implications from FinTech Supervisory and Regulatory Issues that Merit Authorities' Attention. Financial Stability Board: June, 2017

FSDT. (2012). National Baseline Survey on Micro, Small and Medium Enterprises in Tanzania. Financial Sector Deepening Trust (FSDT), Dar es Salaam, 2012.

FSDT. (2017). Finscope Surveys, 20019, 2013,2017. Dar-es-Salaam, Tanzania.

Hongbo, D., Xiaojie, H., \& Hongbo, Y. (2009). An Analysis of Causes for SMEees Financing Difficulty. International Journal of Business Management, 4(6), 73-77.

IPC. (2018). Tanzania credit market diagnostic. Presentation made at a workshop held at the Bank of Tanzania, Dar es Salaam, June 11, 2018.

Khraisha, T., \& Artur, K. ( 2018). Can we have a general theory of financial innovation process? Center for Network Science, Central European University, Nador u. 9, Budapest H-1051, Hungary. https://doi.org/10.1186/s40854-018-0088-y

Kimuyu, P. K., \&Omiti, J. (2000). Institutional impediments to access to credit by micro and small-scale enterprises in Kenya. Macmillan Publishers, Nairobi, Kenya.

Lerner, J., \& Tufano, P. (2011). The consequences of financial innovation: A counterfactual research agenda. Annual Review of Financial Economics, 3(1), 41-85. https://doi.org/10.1146/annurev.financial.050808.114326

Marwa, N. (2014). Micro, small and medium enterprises' external financing challenges: The role of formal financial institutions and development finance intervention in Tanzania. International Journal of Trade, Economics and Finance, 5(3), June 2014. https://doi.org/10.7763/IJTEF.2014.V5.376

Mbowe, W. E. (2010). Tanzania Financial Reforms Development. ISBN 978-9976-89-125-6, Dar es Salaam, Tanzania.

Mbowe, W. E. (2018). Innovations Drive Financial Inclusion in Tanzania. African Review, Alain Charles Publishing, London.

Mckinnon, R. I. (1973). Money and capital in economic development. Washington DC: Brookings Institution.

Merton, R. (1995). Financial innovation and the management regulation of financial institutions. Journal of banking and Finance, 19(3-4), June 1995. https://doi.org/10.1016/0378-4266(94)00133-N 
Mishra, P. K. (2008). Financial innovation in emerging markets-Possible benefits and risks. Social Science Research Network Working Paper Series 1262650. https://doi.org/10.2139/ssrn.1262650

Olomi, D., \& Urassa, G. (2008). The constraints to access to capital by SMEs of Tanzania. REPOA, Dar es Salaam.

Osano, M., \& Languitone, H. (2016). Factors influencing access to finance by SMEs in Mozambique: Case of SMEs in Maputo Central Business District. Journal of Innovation and Entrepreneurship, 5(1), 1. https://doi.org/10.1186/s13731-016-0041-0

Reichheld, F., \& Sasser, W. (1990). Zero defections. Quality comes to services. Harvard Business Review, 68(5), $105-111$.

Shaw, E. (1973). Financial deepening in economic development. New York: Oxford University Press.

Stigliz. J (2010). Reforming the international monetary and financial system in the wake of the global crisis. The New Press, New York.

UNIDO. (2013). Tanzania SME Development Policy 2003. Ten Years after Implementation Review, March, 2013.

UNITED NATIONS. (2005). Improving the competitiveness of SMEs through enhancing productive capacity. United Nations New York and Geneva, 2005.

Waari, D. \& Mwangi, W. (2015). Factors influencing access to finance by micro, small and medium enterprises in Meru County, Kenya. International Journal of Economics, Commerce and Management, United Kingdom, III(4), April 2015.

Watanabe, W. (2005). How are loans by their main bank priced? The bank effects, the information and non-price terms of a contract. RIETI Discussion Paper Series 05-E-028.

Yitayal, A. (2004). Determinants of smallholder farmers access to formal credit: the case of Metema Woreda North Gondar in Ethiopia. Addis Ababa: The World Bank Report.

Notes:

${ }^{\mathrm{i}}$ For example, the number of the number of banking institutions increased from six in 1991 to 67 in 2017, with 824 branches across the country. This contributed to the improvement in the share of bank credit to private sector to 16 percent of GDP at the end of 2016 from 4.2 percent at the end of 2000.

ii The term "MSME" is used to refer to micro, small and medium sized enterprises, which is normally used interchangeably with SME in Tanzania. As per government definition, SME engage in non-farm economic activities largely manufacturing, mining, commerce and services. Micro enterprises employ 1-4 people and have capital investment of up to TZS 5 million; small enterprises, 5-49 people and capital of above 5 million to 200 million; and medium enterprises, 50-99 people and capital of above 200 million to TZS 800,000.

iii Accounting for seasonality, Diao et al. (2016) suggest a lower value added of 13.5 percent of national GDP.

iv See, FSDT, https://www.fsdt.or.tz/sme-finance/, accessed on 30 October 2019.

${ }^{v}$ BoT (op.cit.).

${ }^{v i}$ Mobile money registered accounts, for example, reached 76.1 million at the end of September 2017; with 17.6

million active users, more than double the number of users in 2012.

vii The uniqueness of this definition is that it recognizes that financial innovation does not necessarily come from financial institutions. This is in contrast with for example, Schumpeter's "the introduction of new or qualitative change in existing products, processes, markets, sources of supply of inputs, and organizations" (Arthur, 2009) or "creation and the popularization of new financial products, processes, markets, and institutions" as accepted by Mishra (2008), and Lerner and Tufano (2011).

viii The approach is more preferred because high concentration of SMEs in a region could imply higher economic activities and thus demand for loan. 


\section{Appendices}

Appendix I. Description of variables and expected coefficient signs

\begin{tabular}{|c|c|c|c|c|}
\hline Variable & Information & Hypothesis/Dummy & & Expected coefficient sign \\
\hline A & Access to credit & 1 if accessed credit & 0 if otherwise & Dependent variable \\
\hline$\chi_{1}$ & Need for credit & 1 if needs credit for various reasons & 0 if otherwise & Positive \\
\hline$\chi_{2}$ & Age of business owner & 1 if less than 30 years & 0 if otherwise & $\begin{array}{l}\text { Positive, but negative if old } \\
\text { age }\end{array}$ \\
\hline$\chi_{3}$ & $\begin{array}{l}\text { Gender of the business } \\
\text { owner }\end{array}$ & 1 if male & 0 if otherwise & Positive \\
\hline$\chi_{4}$ & $\begin{array}{l}\text { Level of business } \\
\text { owner's education }\end{array}$ & 1 if no education & 0 if otherwise & Negative \\
\hline$\chi_{5}$ & $\begin{array}{l}\text { Distance between } \\
\text { lender and borrower }\end{array}$ & 1 if less than 5 kilometres & 0 if otherwise & Positive \\
\hline$\chi_{6}$ & $\begin{array}{l}\text { Borrower's perception } \\
\text { about borrowing }\end{array}$ & 1 if perceives it to be a good undertaking & 0 if otherwise & Positive \\
\hline$\chi_{7}$ & $\begin{array}{l}\text { Perception about loan } \\
\text { default risk }\end{array}$ & $\begin{array}{l}1 \text { if perceives the possibility of losing the } \\
\text { collateral }\end{array}$ & 0 if otherwise & Negative \\
\hline$\chi_{8}$ & $\begin{array}{l}\text { Role of innovation (a } \\
\text { type of lending } \\
\text { institution) }\end{array}$ & $\begin{array}{l}1 \text { if innovative platform (SACCOs, } \\
\text { VIKOBA, mobile loan facility, MFIs, } \\
\text { lease or contract financing) is accessed }\end{array}$ & 0 if otherwise & Positive \\
\hline$\chi_{9}$ & Size of loan & 1 if less than 500,000 shillings & & Negative \\
\hline$\chi_{10}$ & Loan repayment period & 1 if less than one month & & Negative \\
\hline
\end{tabular}

Appendix II: Respondents characteristics and business capital investment

Appendix IIA: Respondents characteristics

\begin{tabular}{|l|l|c|}
\hline Group & \multicolumn{1}{|c|}{ Description } & \multicolumn{1}{|c|}{ Percent } \\
\hline \multirow{4}{*}{ Gender } & Male & 28.3 \\
\cline { 2 - 3 } & Female & 13.8 \\
\hline \multirow{5}{*}{ Level of education } & below 30 years & 64.2 \\
\cline { 2 - 3 } & between 30 and 50 years & 22.0 \\
\cline { 2 - 3 } & Above 50 years & 4.4 \\
\hline & No formal education & 39.9 \\
\cline { 2 - 3 } & Primary education & 32.7 \\
\cline { 2 - 3 } & Secondary education & 8.2 \\
\cline { 2 - 3 } & Diploma or technical education, e.g. VETA & 14.8 \\
\cline { 2 - 3 } & Degree or higher degrees & \multicolumn{2}{|c|}{} \\
\hline
\end{tabular}


Appendix IIB: Business capital investment (percent)

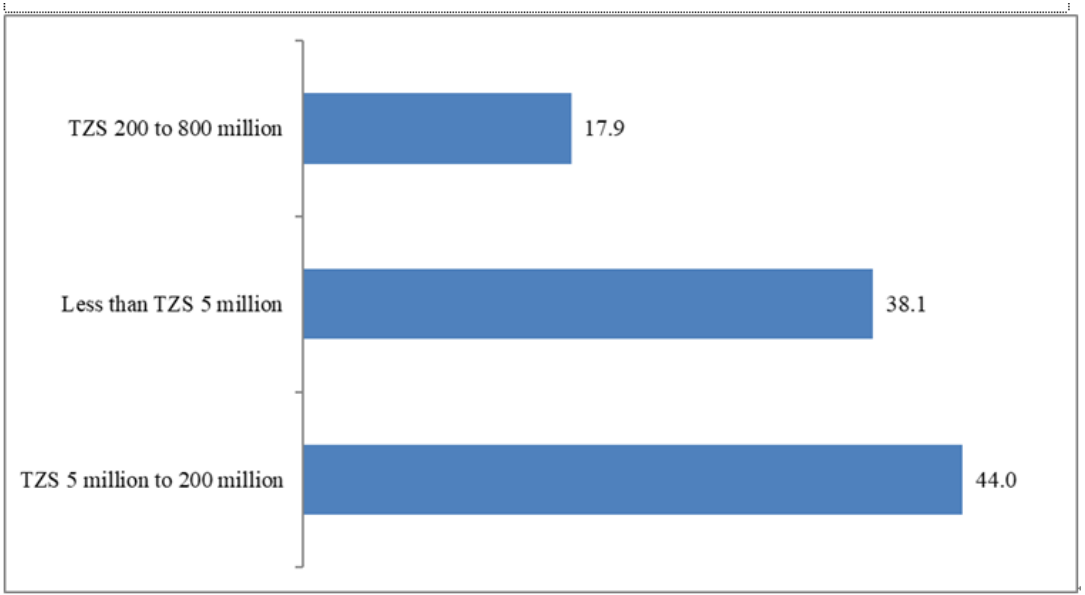

\section{Appendix III: Main purpose for borrowing and areas for credit access improvement}

Appendix IIIA: Main purpose for borrowing loans (All Institutions, percent)

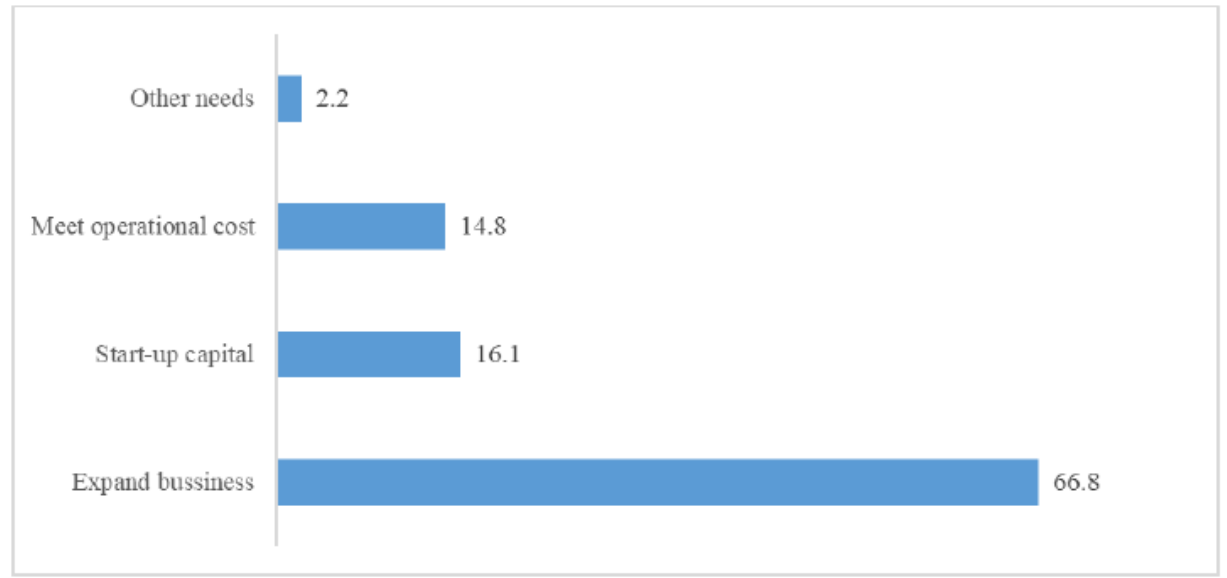

Appendix IIIB: Ranking of areas of improvement to increase overall access to credit (All institutions, \%)

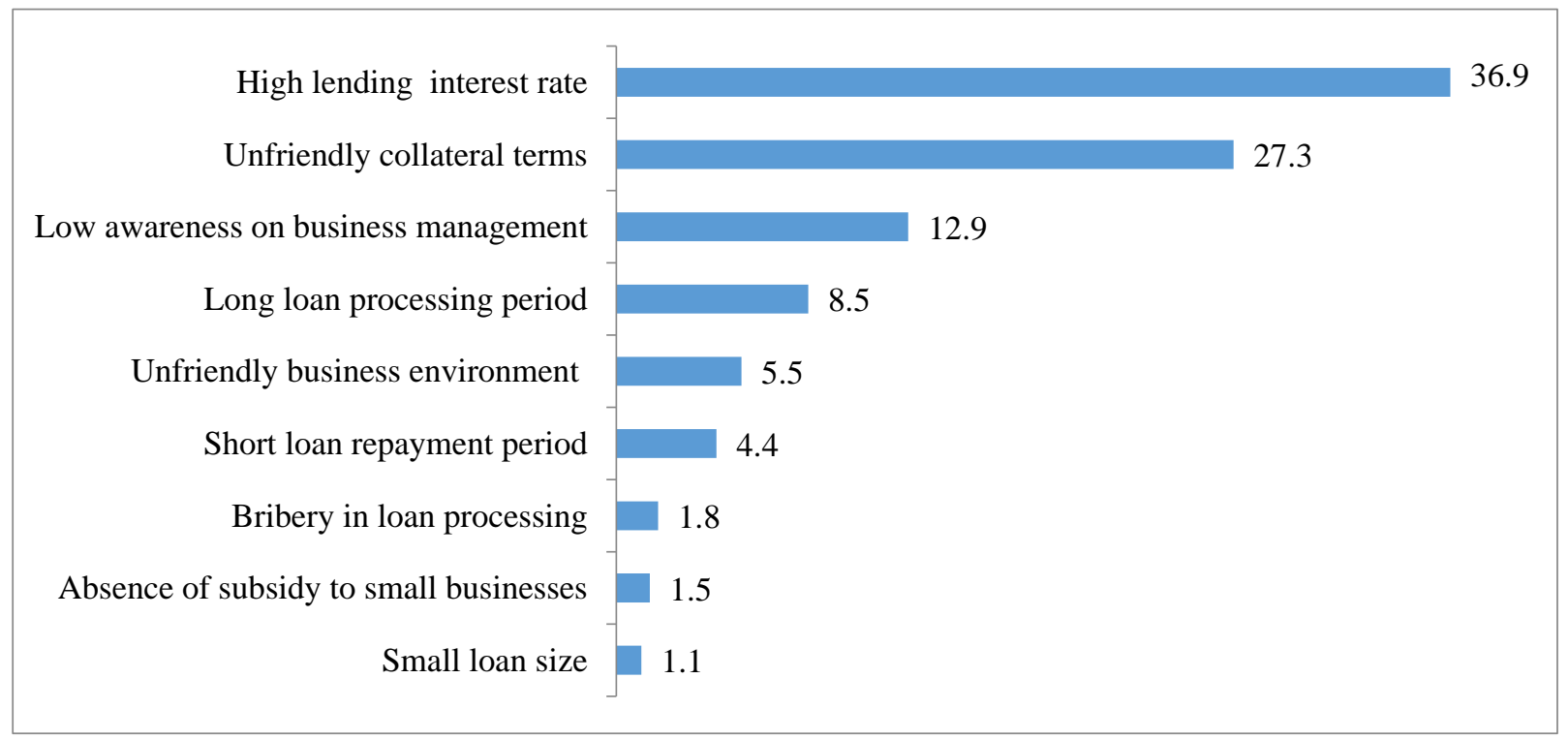


Appendix IV. Summary statistics

Summary Statistics, using the observations 1 - 318

(missing values were skipped)

\begin{tabular}{|c|c|c|c|c|c|}
\hline Variable & Mean & Median & S.D. & Min & Max \\
\hline Credit access & 0.660 & 1.00 & 0.474 & 0.00 & 1.00 \\
\hline Age $30-50$ & 0.642 & 1.00 & 0.480 & 0.00 & 1.00 \\
\hline Age above 50 & 0.220 & 0.00 & 0.415 & 0.00 & 1.00 \\
\hline Gender (male) & 0.783 & 1.00 & 0.413 & 0.00 & 1.00 \\
\hline Primary education & 0.399 & 0.00 & 0.491 & 0.00 & 1.00 \\
\hline Secondary education & 0.327 & 0.00 & 0.470 & 0.00 & 1.00 \\
\hline Technical education & 0.0818 & 0.00 & 0.274 & 0.00 & 1.00 \\
\hline Degree education & 0.148 & 0.00 & 0.355 & 0.00 & 1.00 \\
\hline Distance above $5 \mathrm{~km}$ & 0.256 & 0.00 & 0.437 & 0.00 & 1.00 \\
\hline Loan process easy & 0.610 & 1.00 & 0.489 & 0.00 & 1.00 \\
\hline Loan risky & 0.962 & 1.00 & 0.191 & 0.00 & 1.00 \\
\hline Loan 500,000-5 million & 0.409 & 0.00 & 0.492 & 0.00 & 1.00 \\
\hline Loan 5-25 million & 0.189 & 0.00 & 0.392 & 0.00 & 1.00 \\
\hline Loan above 25 million & 0.138 & 0.00 & 0.346 & 0.00 & 1.00 \\
\hline Loan repayment period & 11.1 & 12.0 & 12.4 & 1.00 & 84.0 \\
\hline Business size & $4.76 e+008$ & $9.00 \mathrm{e}+006$ & $5.76 e+009$ & $2.50 \mathrm{e}+004$ & $1.02 \mathrm{e}+011$ \\
\hline Innovation & 0.214 & 0.00 & 0.411 & 0.00 & 1.00 \\
\hline
\end{tabular}

Source: Authors' estimation

\section{Copyrights}

Copyright for this article is retained by the author(s), with first publication rights granted to the journal.

This is an open-access article distributed under the terms and conditions of the Creative Commons Attribution license which permits unrestricted use, distribution, and reproduction in any medium, provided the original work is properly cited. 